\title{
MORPHOLOGICAL AND HISTOCHEMICAL TYPE DIFFERENTIATION OF MUSCLE FIBRES IN NEWBORN PIGLETS OF THE VIETNAMESE BREED
}

\author{
J. KAMAN* \\ Department of Pathological Morphology, University of Veterinary and Pharmaceutical Sciences, \\ 61242 Brno
}

Received September 28, 1992

\begin{abstract}
Kaman J.: Morphological and Histochemical Type Differentiation of Muscle Fibres in Newborn Piglets of the Vietnamese Breed. Acta Vet. Brno, 62, 1993: 139-149.

A standard histological technique and a histochemical detection of myosin $\mathrm{Ca}$ ATPase with acid and alkaline pre-incubation were used in a study of 11 topographically and functionally different muscles in 11 male and female newborn piglets. Both extra- and intrafusal muscle fibres (MFs) of the newborns were fully morphologically and adequately histochemically differentiated. The myosin CaATPase detection method was used to differentiate between acid stable and alkali unstable muscle fibres of Type I, alkali stable and acid unstable muscle fibres of Type II (in some cases differentiated further into muscle fibres of Type IIA and IIB), and the intermediary muscle fibres of Type IIC with the MS, SS and, sporadically also SM subtypes transforming into Type I fibres. An objective type identification of muscle fibres is only possible when a comparison of myosin Ca-ATPase reactions in serial sections after acid and alkaline pre-incubations are made.

The muscles examined were classified into two basic groups. Those with a higher number $(2-7)$ of Type IIC fibres in the primary bundle (m. sternomastoideus, $\mathrm{m}$. trapezius, $\mathrm{m}$. tibialis cranialis) exhibited better morphological, and particularly histochemical, differentiation than others: these were characterized by a smaller number of Type IIC fibres with largely uniform morphological, but different histochemical, characteristics on the surface as well as in deep in the muscle.

In view of our findings and because pigs belong to nidifugous mammals, we reject the views suggesting that the myofibrillar hypoplasia of muscle fibres in newborn piglets of meat breeds is a "physiological" phenomenon.
\end{abstract}

Skeletal muscles, muscle fibre, morphological differentiation, type differentiation, histochemistry, myofibrillar hypoplasia, splayleg, Vietnamese pig, newborn pig

Thurley (1967) described a congenital functional motility disorder in newborn piglets and called it splayleg. The extent of the disorder may vary but the pelvic limbs tend to be affected more severely and more frequently. In really severe cases, animals collapse in a characteristic position with splayed legs, and are unable to move or stand up. From the morphological point of view, the disorder is described as myofibrillar hypoplasia (MFH) (Thurley, Gilbert, Done 1967, Thurley, Done 1969) or myofibrillar retardation (MFR) (Kaman, Pivník, Lukáš 1977), discernible in transversal sections of skeletal muscles as a myofibrillar deficiency of muscle fibres, varying in size and reaching sometimes $100 \%$. Although Thurley et al. (1967), Köhler, Seffner (1975) and other authors relate $\mathrm{MFH}$ to splayleg, it has also been found in piglets in herds free of any clinical manifestations of splayleg (Kaman et al. 1977). Zelená, Jirmanová 1979, Ward 1980, Cox, Ward, Baskerville 1979 therefore believe that the determining factor is the degree of $\mathrm{MFH}$, rather than its presence or absence. Done (1979) tried to quantify $\mathrm{MFH}$ microscopically. He, however, found that its variability in individual histological sections

Present address: Sumavská 25, 60200 Brno 
was so extensive that no practical correlation with splayleg was possible. Cox et al. (1979) also attempted a similar quantification on the $\mathrm{m}$. semitendinosus. They used two Landrace herds, one of which was affected with splayleg, the other was not. They did not see the difference in the extent of MFH but in the highly significant variations in the arrangement of myofibrils in muscle bundles in animals affected and unaffected by splayleg.

And, finally, Schlotke and Koch (1978) considered MFH of muscle fibres (MFs) in meat breeds of pigs as a "common phenomenon" and Lojda et al. (1983) as "partly physiological". Mesároš et al. (1981) arrived at a rather strange conclusion when they said that "myofibrillar hypoplasia of MFs is certainly quite common, if not physiological, in meat breeds of pigs". Newborn piglets are nidifugous. They can stand up shortly after birth, begin to move around and they leave their nest. This is true about the wild pig as well as the domestic one. A fundamental prerequisite of physiological motility is an adequate differentiation of skeletal muscle fibres. Setting out from this hypothesis and the above literary data, we aimed our research at the study of morphological and histochemical type differentiation of MFs in selected skeletal muscles of newborn piglets of the primitive Vietnamese breed.

\section{Material and Methods}

In our research, we used 11 piglets of the Vietnamese breed from 5 litters from two zoological gardens in this country. Piglets of both sexes were represented. They were 2 to $22 \mathrm{hrs}$ old and weighed $250-400 \mathrm{~g}$.

Of a total of 13 topographically and functionally different muscles, 5 to 8 muscles in different combinations were examined in individual piglets. Their final number eventually stabilized at seven: $\mathrm{m}$. trapezius, $\mathrm{m}$. longissimus dorsi, caput longum $\mathrm{m}$. tricipitis brachii, $\mathrm{m}$. gracilis, $\mathrm{m}$. semimembranosus, $\mathrm{m}$. tibialis cranialis and $\mathrm{m}$. sternomastoideus. Standard biopsy was performed and specimens were removed from all animals either under general ether anaesthesia, or immediately after the animals were sacrificed. A part of each specimen was deep frozen to about $-190^{\circ} \mathrm{C}$ in propane-butane cooled with liquid nitrogen or in $\mathrm{N}_{2}$ directly. It was then deposited at $-60^{\circ} \mathrm{C}$ and $10 \mu \mathrm{m}$ thick cryostat sections were made at $-20^{\circ} \mathrm{C}$.

The rest of the specimen was fixed at $10 \%$ formalin, embedded in paraffin and used for serial histological sections $8-10 \mu \mathrm{m}$ thick. In both cases, the sections were stained with hematoxylineosin (HE) to highlight their microstructure. Histochemical differentiation and type classification of MFs were carried out on serial sections by detecting myosin Ca-ATPase and comparing the results after an alkaline $(\mathrm{pH} 9.2 ; 9.4)$ and acid $(\mathrm{pH} 4.3 ; 4.6)$ pre-incubation (Dubowitz, Brooke 1973, Lojda, Papoušek 1978, Suzuki, Cassens 1980).

For the type identification of MFs, the nomenclature proposed by Suzuki and Cassens (1980) was used. These authors distinguished between MF I (red), MF II (white) and an intermediate MF IIC, transforming through subtypes $M S \rightarrow S S \rightarrow S M \rightarrow M F$ I. Type II fibres are enzymohistochemically differentiated postnatally and, to a varying extent and degree, already in neonates into MF IIA and MF IIB.

\section{Results}

M. trapezius - both cryostat and paraffin hematoxylin-eosin histological sections show a complete morphological differentiation of extrafusal as well as intrafusal muscle fibres. They are completely filled with myofibrils; cellular nuclei are situated subsarcolemmally (Plate XVIII., Figs 1,2). They are usually close to each other, fill the entire space of the primary muscle bundle (MB) and on the transversal cross-section (CS), they are no longer circular but have acquired, or are in the process of acquiring, various polygonal shapes. Any differences in thickness between muscle fibres of the primary and secondary development populations (corresponding to MF I and II respectively) have been largely, if not completely, eliminated and their differentiation according to thickness is no longer possible. In most cases, the muscle looks compact, with the primary and frequently also the secondary bundles not clearly delineated.

Neuromuscular spindles were also fully differentiated. They contained $1-2$ conspicuously thicker completely filled fibres and 3-8 (in a few cases even more) 
fibres 2-3 times thinner. The cell nuclei were elongated or circular, located subsarcolemmally, frequently also centrally or intrafibrally.

Enzymohistochemical detection of myosin Ca-ATPase in the m. trapezius (Plate XVIII., Figs 3, 4) not only fully confirmed the morphological differentiation of its fibres but also their adequate histochemical and type differentiation. The myosin Ca-ATPase reaction after an acid pre-incubation at $\mathrm{pH} 4.3$ helped identify $1-7$ well-differentiated grey-black or bleck reacting acidostable MFs corresponding to Type I fibres, and those of the intermediary type IIC clustered around Type I fibres, or partially dispersed throughout the muscle bundle. The rest of the primary $M B$ was filled with fibres exhibiting significantly lower intensity of the ATPase reaction, which sometimes dropped to almost zero. They correspond to Type II fibres (white). They are considered more primitive and less differentiated. In places (Fig. 3) they may, however, be differentiated into Type IIA and IIB fibres; the former are slightly lighter in colour, they may have a negative reaction, while the latter show a moderate reaction. In detecting myosin Ca-ATPase activity following alkaline pre-incubation, both MFs react strongly, although the IIA fibres slightly less so. Their objective identification, however, would be impossible without a comparison of their serial cross-sections with ATPase reaction following an acid pre-incubation.

A comparison between a Ca-ATPase reaction after an acid pre-incubation (particularly at $\mathrm{pH}$ 4.6) and a Ca-ATPase reaction after an alkaline pre-incubation allowed a differentiation of transformation subtypes MS, SS and, in some cases, even SM of the intermediary Type IIC fibres in their conversion to MF I.

The ATPase reaction after an alkaline pre-incubation was manifested as an inversion of the ATPase reaction after an acid pre-incubation. It was generally possible to differentiate 3 degrees of its intensity, corresponding to a differentiation of fibres into Types I, II and IIC, with the weakest or even negative reaction in alkali unstable Type I fibres, weak to strong reaction in the transformation Type IIC fibres, and the strongest reaction in alkali stable Type II fibres situated along the periphery of primary MBs. Type IIA and IIB fibres can hardly be differentiated, if at all, without a comparison being made between ATPase reactions in serial sections after an alkaline and acid pre-incubation.

M. longissimus dorsi - while histological sections of the $\mathrm{m}$. trapezius show a relatively uniform distribution of muscle bundles consisting, for the most part, of secondary MBs with often merging primary bundles, in $\mathrm{m}$. longissimus dorsi two markedly different areas were identified. In the deeper and more compact one, the primary bundles were not clearly delineated, they often merged and even the secondary ones were sometimes impossible to distinguish. In crosssections, muscle fibres are polygonal to a varying degree, differences in thickness between muscle fibres of the first and second populations are gradually disappearing and are almost imperceptible in some places. The more extensive outer zone of the muscle, on the other hand, is markedly less compact, with clearly identifiable primary and, particularly, secondary muscle bundles, delineated with abundant connective tissue. The contact of fibres in muscle bundles is relatively loose, which accounts for their more or less circular CS. Muscle fibres are fully differentiated and completely filled with myofibrils, and the cross striation of muscle fibres can be observed not only in histological sections stained with hematoxylin-eosin but also in myosin ATPase detection. Remains of myotube lumina or centrally located cell nuclei can be found sporadically. The difference in thicknesses of the primary and secondary populations of MFs is retained 
to a varying degree. Type I fibres in the centre of the muscle bundle may be several times thicker than those of Type II. In this case, they can also be differentiated in sections stained with hematoxylin-eosin.

In two piglets whose birth weight was very low we found symptoms of myofibrillar hypoplasia, although they were absolutely insignificant in scope and intensity (Plate XIX., Fig. 5).

Fig. 6 (Plate XIX.) of a surface area of the m. longissimus dorsi documents not only a highly significant reaction of myosin Ca-ATPase after an alkaline preincubation but also a complete enzyme-histochemical type differentiation of its muscle fibres. In the centre of the primary muscle bundle, we observed 1 (rarely 2) alkali unstable muscle fibres of the first development population (MF I), conspicuous for their thickness and a very faint-to-negative histochemical reaction. Clearly predominating in the muscle bundle were alkali stable (MF II) muscle fibres of the second generation showing a strong reaction. One to three (mostly two) clearly visible and fully differentiated muscle fibres of the intermediary type IIC are located paracentrally of MF I. They represent a transformation from Type II into Type I fibres. In thickness and intensity of their histochemical reaction they fall between these two types. They are only slightly thinner than MF I but thicker than MF II and the intensity of their reaction depends on what stage of transformation between Type IIC and Type I they find themselves in. In primary bundles of the mi. longissimi dorsi, MS and SS subtypes of the intermediary type IIC and, more rarely, its SM subtype, can be distinguished (see Fig. 6). In the ATPase reaction after an acid and alkaline pre-incubation, the MS subtype reaction is moderate and strong, respectively; the intensity of the SS type reaction is strong in both cases, and that of the SM subtype is strong after an acid pre-incubation and weak after an alkaline one. An objective identification of these subtypes is only made possible by a comparison of the myosin Ca-ATPase activity in serial histological sections after acid and alkaline pre-incubations (Plate XX., Fig. 7).

The reaction of the myosin Ca-ATPase after an acid pre-incubation was an inversion of the same reaction after an alkaline pre-incubation. Type I fibres that have a weak reaction after an alkaline pre-incubation showed a strong positive reaction due to their acid stability, while the reaction intensity of acid unstable fibres of Type II was weak. Four to 5 degrees of intensity of the ATPase reaction were distinguished in some places where a strong reaction was identified not only in Type I fibres but also in a group of 2-3 muscle fibres of Type IIC situated around Type I fibres. They correspond to the already-mentioned subtypes of IIC fibres, i.e. MS, SS and SM. The remaining muscle fibres of the secondary development population, MF II, are acid unstable and the intensity of their reaction is weak. From time to time, we may come across their more or less pronounced differentiation into MF IIA and IIB. For their identification, a comparison between the myosin Ca-ATPase reaction after an acid and alkaline preincubation is essential.

M. triceps brachii, caput longum - most extrafusal and intrafusal fibres appeared fully morphologically differentiated, the thickness of both development populations of fibres (MF I : MF II) appeared largely balanced; in some areas of histological sections, the MF II are even thicker than MF I (Plates XX., XXI., Figs 8, 9, 10). In spite of that, fibres situated centrally in muscle bundles with remains of a myotube luminum or a centrally located cell nucleus identifying them as Type I fibres may occur in some individuals occasionally. 
The delineation of primary muscle bundles is seldom clear enough to allow an accurate determination of their boundaries. Fibre cross-sections were mostly polygonal in shape, which is due to a close contact between muscle fibres and a relative compactnes of the muscle.

By myosin Ca-ATPase detection following an alkaline pre-incubation, we were able to identify an absolute predominance of Type II fibres in primary bundles, with 1-2 (mostly 1) slightly reacting Type I fibres in its centre. After an acid pre-incubation, two areas were distinguished in histological sections: a larger one, closer to the muscle surface, usually containing only 1 acid stable fibre in the primary bundle and a smaller area, deeper in the muscle, containing 2-3 such fibres.

Caput laterale mi. tricipitis brachii shows no fundamental morphological difference in histological sections from caput longum mi. tricipitis brachii. Histochemically, by ATPase detection, we identified $1-3$ alkali unstable fibres in the primary bundle after an alkaline pre-incubation, and 1-4 (mostly 2-3) acid stable muscle fibres in an inverse reaction after an acid pre-incubation. This shows a tendency to a mixed muscle.

$M$. semimembranosus - muscle fibres in a majority of newborns are completely filled with myofibrils of the same thicknes. Thelr crossection may have already acquireda polygonal shape but its Type I fibres are still thicker than Type II fibres and circular ones. In two piglets of low weight, a very slight myofibrillar deficiency extending over about $5 \%$ of a histological section was found in preparations from the caudal surface area of the muscle.

In these morphologically uniform preparations, the myosin ATPase reaction differentiated between two areas: the surface area containing a single fibre of Type I after both alkaline and acid pre--incubations, and the deeper area containing 1-2 (rarely 3) alkali unstable muscle fibres after an alkaline pre-incubation and $1-5$ (mostly $2-3$ ) acid stable ones after an acid pre-incubation.

$M$. semitendinosus generally displays all the symptoms of a morphologically fully differentiated muscle. Muscle fibres are of an almost uniform thickness. Fibres with a circular CS predominate although the number of those with a polygonal CS is also quite large. Sporadic occurrence of MFs with remains of myotube lumina was seen. Some general analogy with $\mathrm{m}$. semimembranous could be found. The most frequent findings in a myosin ATPase detection after $\mathrm{pH} 4.3$ pre-incubation were 1 and $2-4$ acid stable muscle fibres in the surface and deep layers, respectively.

M. tibialis cranialis - transversal histological sections provided preparations from its entire thickness. With the exception of one newborn piglet where fibres exhibiting slight myofibrillar deficiency were found in the surface layer of the muscle in larger quantities, the muscle was adequately differentiated in all cases and the fibres, mostly of a uniform thickness, were entirely filled with myofibrils. The muscle had a compact structure and primary muscle bundles were seldom clearly differentiated.

In areas of myofibrillar deficiency, the usually positive myosin ATPase reaction was attenuated or entirely negative. Two areas were identified in this muscle: a surface area with 1-2 fibres in the primary bundle, and a deeper area with $2-3$ (or more) fibres, both groups reacting strongly at a pre-incubation at $\mathrm{pH} 4.3$.

M. sternomastoideus demonstrates a completed morphological differentiation of muscle fibres. While extrafusal fibres are of a uniform thickness and 
mostly of a polygonal cross-section with cellular nuclei situated subsarcolemmally, intrafusal fibres differ in their thickness, their cross-section is more circular in shape, with cell nuclei situated both subsarcolemmally and intrafibrally, and filled with myofibrils in both cases.

The detection of myosin Ca-ATPase after an alkaline pre-incubation commonly differentiated between $2-3$ degrees of a reaction intensity. In the primary $M B$, 3-5 alkali unstable fibres exhibiting a uniform or differentiated weak reaction were found most frequently. They were surrounded by strongly reacting Type II fibres. After an acid pre-incubation, the intensity of the reaction product differentiated up to 4 types of muscle fibres, corresponding to Types II, I and IIC with its transformation subtypes. In the primary muscle bundle, 2-12 acid stable fibres with a different intensity of reaction can be identified. They represent a substantial part of the total number of fibres in the muscle bundle. The remaining fibres of the primary $\mathrm{MB}$ are weakly reacting muscle fibres of Type II.

M. extensor carpi radialis - its most conspicuous features in preparations with a fully differentiated fibres include their uniform thickness, the polygonal shape of the CS and cross striation on their longitudinal secitons. The myosin Ca-ATPase detection shows a tendency to a reduced histochemical differentiation of fibres after an alkaline pre-incubation at $\mathrm{pH}$ 9.4. In primary muscle bundles, $1-2$ (rarely 3 ) alkali unstable fibres were found after an alkaline pre-incubation, and 1-2 (less frequently 3 and exceptionally 4 ) acid stable fibres were found after an acid pre-incubation.

M. gracilis - in this adequately differentiated muscle, the most prominent are fibres completely filled with myofibrils, in most cases clearly delineated primary muscle bundles, relatively thin fibres of a circular transversal cross-section and muscle fibres of the primary development population, still thicker in some cases than the fibres of the second population. Striation in longitudinal sections of MFs is clearly visible.

The ATPase reaction after an alkaline pre-incubation may sometimes be monotonous, offering no possibility for a type differentiation. In other cases, the reaction intensity of 1-2 muscle fibres located centrally in the muscle bundle is low, while other fibres of the primary bundle show a strong reaction. The reaction after an acid pre-incubation is usually more unambiguous. It helps detect 1 , often $2-3$ and sometimes up to 5 fibres in the centre of the primary muscle bundle whose reaction intensity is strong, and other fibres in its periphery which have a low reaction intensity.

The remaining muscles, $\mathrm{m}$. pectoralis transversus and $\mathrm{m}$. rectus femoris on the one hand and m. gluteus medius on the other were examined in cryostat and paraffin histological sections, respectively, and stained with hematoxylin-eosin. The primary aim was to determine the morphological myofibrillar differentiation of their muscle fibres. They all had one feature in common, namely that the primary muscle bundles were made up of completely differentiated muscle fibres which were completely filled with myofibrils.

\section{Discusion}

In the prenatal development of porcine skeletal muscle fibres, two fundamental development populations can be distinguished. One is characterized by the development of thick myotubes, i. e. primary muscle fibres growing most rapidly 
(from $7 \mu \mathrm{m}$ to $11 \mu \mathrm{m}$ ) from the 45 th to 55 th day of gestation. They correspond to muscle fibres of Type I (MF I), red. The other, later, population (55-100 days of gestation) is characterized by production of thin, usually non-tubular muscle fibres which come into existence by a fusion of myoblasts around primary fibres. From day 100 after birth, these fibres beging to grow rapidly, while the first population fibres have ceased to grow in size and their proliferation is reduced (Thurley 1972, Swatland and Cassens 1973, Ashmore 1973, Beermann et al. 1978). Lukáš et al. (1978) and Kaman (1985) found that it was the muscle fibres of the second generation corresponding to Type II fibres that were primarily, if not exclusively, affected by myofibrillar hypoplasia (MFH) or retardation (MFR), which manifested themselves as a numerical deficiency of myofibrils in the cross-section of muscle fibres.

We believe that the balancing of differences in thickness between muscle fibres, when one population (MF I) is relatively stable while the other (MF II) is still growing, is one of the substantial indices of morphological differentiation of muscle fibres in newborns. Data on morphological differentiation of muscle fibres in newborn piglets are still scarce. The only muscles examined have been the $\mathrm{m}$. longissimus dorsi and possibly muscles of analogical morphological and metabolical types. The available data on histochemical and type differentiation of muscle fibres in newborn piglets do not provide the necessary information and are also controversial even in cases when referring to a muscle of the same name and same methodology is used. Generally, only two or three types of fibres are distinguished.

While Cooper et al. (1970) failed in their attempt to type differentiate fibres in $\mathrm{m}$. longissimus dorsi by means of a routine ATPase reaction, Davies (1972) successfully differentiated two basic types of fibres in a muscle of the same name, using the same methodology. Ashmore et al. (1973) achieved the same in the $\mathrm{m}$. semitendinosus and $\mathrm{m}$. triceps brachii by comparing the myosin ATPase detection after an alkaline and acid pre-incubation in foetuses at 75 days of gestation. Szentkuti and Cassens (1978) used the same method in porcine foetuses for the $\mathrm{m}$. longissimus dorsi. The same year, Schlotke and Koch (1978) and Lukáš et al. (1978) reported that they successfully differentiated both basic types of muscle fibres (MF I and II) by means of the myosin Ca-ATPase without pre-incubation, i. e. by the so-called routine reaction. According to Swatland (1975) and Hanzlíková (1980), however, the only way to differentiate between porcine neonatal muscle fibres of Types I and II in $\mathrm{m}$. longissimus dorsi is the Ca-ATPase reaction after an acid pre-incubation. Our results demonstrate that this is not quite true because in ATPase detection after an acid pre-incubation, an intensive reaction was shown not only by Type I fibres but also by the intermediary IIC fibres and its MS, SS and SM subtypes.

In neonates of the Vietnamese breed, we found morphologically fully differentiated extra- and intrafusal MFs, characterized primarily by the fact that they were completely filled with myofibrils, subsarcolemmal position of the cell nucleus, cross striation, polygonal shape of the MF cross-section (CS) and balanced thickness of both basic fibre types (I and II) or a tendency towards it. Histochemically, be detecting myosin Ca-ATPase after an acid and alkaline pre-incubation and comparing the results of the two, it was possible to routinely differentiate fibres of Type I, II and IIC; frequently also the transformation of the intermediary muscle fibre of Type IIC in its subtypes MS, SS and sometimes also SM, which is a precursor of MF I in the conversion of MF IIC into MF I. 
Less frequently, differentiation of MF II into MF IIA and IIB was also observed.

With regard to type differentiation, the muscles examined were divided into two groups. One contained muscles of the $\mathrm{m}$. longissimus dorsi type (phasic type) with a single Type I fibre in its primary muscle bundle, and 1-3 (most frequently 2) Type IIC fibres. The other group contained muscles characterized by a higher number (2-7) of Type IIC fibres: they were, first of all, the $\mathrm{m}$. sternomastoideus, $\mathrm{m}$. trapezius and $\mathrm{m}$. tibialis cranialis.

The myofibrillar deficiency of Type II fibres in the m. longissimus, $\mathrm{m}$. semimembranosus and a surface area of the $\mathrm{m}$. tibialis cranialis found in two piglets was related to their below-average body weight. A motility test did not reveal the presence of a clinical syndrome of splayleg in any of the piglets examined. We believe that our results allow us to question the wording and substance of the claims made by some authors who consider myofibrillar hypoplasia of muscle fibres in meet breeds of pigs as a "common phenomenon" (Schlotke and Koch 1978), "partially physiological phenomenon" (Lojda et al. 1983), or "if not directly physiological then certainly a common phenomenon in meat breeds of pigs" (Mesároš et al. 1981). For a pig as a nidifugous mammal that leaves its nest soon after birth, adequately differentiated fibres of skeletal muscles (with a particular emphasis on the differentiation of myofibrils as the active component of MFs) are an essential prerequisite of its existence.

By allowing a type identification of muscle fibres and providing a better understanding of type distribution of fibres in the muscle, histochemical methods also open a new view of the muscle function. This has been pointed out by Beermann, Cassens and Hausman (1978) in the m. semitendinosus of a Yorkshire pig foetus and by Kaman (1985) in the $\mathrm{m}$. semimembranosus of a Duroc breed newborn. While a morphological differentiation presented a uniform picture along the entire cross-section of the muscle, a histochemical method (a detection of myosin Ca-ATPase after an acid pre-incubation) demonstrated only one, more rarely two, acid stable fibres with a strong reaction in the surface area of the muscle, and $2-6$ of them in its deeper layer.

In the present study on porcine neonates of the Vietnamese breed, we observed an analogy to the increased number of acid stable fibres in a deeper layer of a muscle also in the $\mathrm{m}$. longissimus, caput longum et laterale $\mathrm{m}$. tricipitis brachii, $\mathrm{m}$. semimembranosus, $\mathrm{m}$. semitendinosus and $\mathrm{m}$. tibialis cranialis. If the structure of the surface part of the muscles point to a fast twitch muscle, the structure of deeper layers corresponds, to a varying degree, to a mixed muscle.

Beermann et al. (1978) recorded this morphological and histochemical difference in 75 days old porcine foetuses, where primary muscle fibres (MF I) showed a positive reaction to acid pre-incubated ATPase in a deep layer of the $\mathrm{m}$. semitendinosus but not in the surface one. Originally, secondary muscle fibres (MF II) reacted to an acid pre-incubated ATPase negatively along the entire cross-section of the muscle. Later, however, fibres in a deep layer of the muscle adjoining to individual MF I, underwent a conversion from Type II to Type I. It begins between 90 and 105 days of gestation and continues throughout the 3rd week of the postnatal development. Comparing myosin Ca-ATPase reactions after an acid and alkaline pre-incubation, Suzuki and Cassens (1980) demonstrated that the conversion takes place through a transformation of MF IIC and subtypes $\mathrm{MS} \rightarrow \mathrm{SS} \rightarrow \mathrm{SM} \rightarrow \mathrm{SV}$ I, which corresponds to our results.

Differences in the histochemical reaction of the ATPase (Beermann et al. 1978) might then explain the heterogeneity of the ATPase reaction observed 
within a single section and a monotonous reaction without a type differentiation of fibres or even its absence on other occasions, which points to an insufficient histochemical differentiation while providing a conclusive morphological differentiation.

\section{Morfologická a histochemická typová diferenciace svalových vláken u novorozených selat vietnamského plemene}

Prozkoumali jsme běžnou histologickou technikou a histochemicky detekcí myosinové Ca-ATPázy s kyselou a alkalickou preinkubací 11 topograficky a funkčně rozdílných svalů u 11 novorozencủ obou pohlaví. Jak extra-, tak intrafuzální svalová vlákna (SV) novorozenců jsou plně morfologicky a adekvátně histochemicky diferencována. Detekcí myosinové Ca-ATPázy jsme rozlišili acidostabilní a alkalilabilní SV typu I, alkalistabilní a acidolabilní SV typu II (ojediněle diferencovaná ve SV IIA a IIB) a intermediární SV IIC s podtypy MS, SS, sporadicky i SM, transformující ve SV I. Objektivní typová identifikace SV je jedině možná srovnáním reakcí myosinové Ca-ATPázy v sériových řezech po kyselé a alkalické preinkubaci.

Zkoumané svaly se rozlišily ve dvě základní skupiny. Svaly s vyšším počtem (2-7) SV IIC v primárním svalovém snopci (m. sternomastoideus, $\mathrm{m}$. trapezius, m. tibialis cranialis) se jeví morfologicky a zejména histochemicky lépe diferencovány než ostatní, které jsou charakterizovány nižším počtem SV IIC, u většiny jednotným morfologickým, ale rozdílným histochemickým obrazem $\mathrm{v}$ povrchové a v hluboké části svalu.

$S$ přihlédnutím $\mathrm{k}$ našim výsledkům a přislušnosti prasete $\mathrm{k}$ savcům nidifugním, odmítáme názory propagující myofibriální hypoplasii SV u novorozených selat masných plemen prasat jako „fyziologický“ jev.

\section{Морфологическая и гистохимическая типовые дифференциации мышечных волокон новорожденных поросят въетнамской породы}

Проводили исследования обычной гистологической техникой и гистохимической детекцией миозинных Са-АТРаз с кислой и щелочной преинкубацией 11 топографически и функционально разных мышц 11 новорожденных обоих полов. Не только экстра-, но и интрафузальные мышечные волокна (MB) новорожденных морфологически и соответственно гистохимически полностью дифференцированы. Определением миозинной Са-АТРазы различили кислотно стабильные и щелочно неустойчивые МВ типы I, щелочно стабильные и кислотно лабильные МB типа II (в отдельных случаях дифференцированные в МВ IIA и IIB) и интермедиарные МB типи IIC с подтипами MS, SS, спорадически также SM, трансформирующие в МB І. Объективная типовая идентификация МВ единственно возможна взаимным сопоставлением реакции миозинной Са-АТРазы для кислых, с реакцией послещелочной преинкубации в серийных целых.

Исследуемые мышцы были распределены на две основные группы. Мышцы с большей численностью $(2-7)$ MB IIC в первичном мышеч- 
ном пучке (m. sternomastoideus, $m$. trapezius, $m$. tibbialis craniolis) морфологически и, в особенности гистохимически лучше дифференцированы по сравнению с остальными, характеризованными меньшей численностью МВ IIC, у большинства единой морфологической, одна ко разной гистохимической картиной поверхностной и глубокой части мышцы.

Учитывая наши результаты и принадлежность поросят к млекопитающим нидифугного характера, отрицаем взгляды, отстаивающие миофибриллярную гипоплазию МВ новорожденных поросят мясной породы в качестве «физиологического» явления.

\section{References}

ASHMORE, C. R.-ADDIS, P. B.-DOERR, L.: Development of muscle fibres in the fetal pig. J. Anim. Sci., 36, 1973: 1 088-1 093

BEERMANN, D. H. - CASSENS, R. G.-HAUSMAN, G. J.: A second look at fibre type differentiation in porcine skeletal muscle. J. Anim. Sci., 46, 1978: 125-132

COOPER, C. C. - CASSENS, R. G. - KASTENSCHMIDT, L. L. - BRISKEY, E. J.: Histochemical characterization of muscle differentiation. Develop. Biol., 23, 1970: 169-184

COX, C. S. - WARD, P. S. - BASKERVILLE, A.: Quantitative image analysis of skeletal muscle from newborn pigs with myofibrillar hypoplasia and splayleg. Brit. Vet. J., 135, 1979: $370-375$

DAVIES, A. S.: Postnatal changes in the histochemical fibre types of porcine skeletal muscle. J. Anat., 113, 1972: 213-240

DONE, J. T.: Personal communication. Cit. in COX et al.: Quantitative image analysis of skeletal muscle from newborn pigs with myofibrillar hypoplasia and splayleg. Brit. Vet. J., 135, 1979: $370-375$

DUBOWITZ, V.-BROOKE, M. H.: Muscle biopsy: A modern approach. Saunders Company Ltd., London, 1973, $475 \mathrm{p}$.

HANZLÍKOVA, V.: Histochemical patterns in normal and splayleged muscle fibres. Histochemistry, 67, 1980: $311-319$

KAMAN, J.: Morphological and Enzymhistochemical Differentiation of Muscle Fibres in Newborn Pigs and it Relation to Acute Myopathy. Final Report of VU No. VI-5-15/05, UVPS Brno, 1985 (in Czech)

KAMAN, J.-PIVNÍK, L.-LUKÁŠ, Z.: Retardation phenomenon in histogenesis of the muscle fibres of the fleshy type of pig. Folia Morphol., 25, 1977: 360-363

KÖHLER, R. - SEFFNER, W.: Angeborenes Beinspreizen bei Saugferkeln. Mh. Vet. Med., 30, 1975: 259-262

LOJDA, L. - HOŘfNOVÁ, Z. - LOJDA, Z. - BÖHM, R.: Experimental Assay of the Principal Etiological Factor in the Onset of Splayleg Syndrome in Piglets. Veterinary Care in Large-Scale Rearing Facilities, Institute of Veterinary Education Pardubice, 1983, 17 p. (in Czech)

LOJDA, Z. - PAPOUŠEK, F.: Fundamental Principles of Histochemical Assay of Enzymes. Institute for Further Education of Paramedical Personnel, Brno, 1978, $119 \mathrm{p}$. (in Czech)

LUKÁS, Z. - PIVNÍK, L. - STRAKA, I.-RAMPOCHOVÁ, J. - ŠTĚPÁNOVÁ, L.KAMAN, J.: Morphological and histochemical type differentiation of the primary and secondary foetal muscle fibres in neonatal piglets. Zbl. Vet. Med. A., 29, 1982: 107-122

LUKÁS, Z. - KAMAN, J. - PIVNIK, L.: Histochemical characteristics of the splayleg syndrome in newborn piglets. Acta vet. Brno, 47, 1978: 51-66

MESAROŠ, E. - PIVNÍK, L. - VAŘEJČKO, J. - REHÁK, A.: Shall We Get Rid of Splayleg in Piglets? Veterinářství (Veterinary Science Journal), 31, 1981: 266-286 (in Czech)

SCHLOTKE, B. - KOCH, F.: Histochemische Untersuchungen zur Entwicklung der Skelettmuskulatur des Ferkels in der Neugeborenenphase. Zbl. Vet. Med. A., 25, 1978: 129-137

SUZUKI, A. - CASSENS, R. G.: A histochemical study of myofiber type in muscle of the growing pig. J. Anim. Sci., 51, 1980: 1 449-1 461

SWATLAND, H. J.: Histochemical development of myofibres in neonatal piglets. Res. Vet. Sci., 18, 1975: 253-257

SWATLAND, H. J. - CASSENS, R. G.: Prenatal development, histochemistry and innervation of porcine muscle. J. Anim. Sci., 36, 1973: 343-354 
SZENTKUTI, L.-CASSENS, R. G.: Die Verteilung der Fasertypen I, IIA und IIB im M. longissimus dorsi und M. semitendinosus von Schweinen verschiedenen Alters. Dtsch. Tierärztl. Wschr., 85, 1978: 23-28

THURLEY, D. C.: Muskulaturentwicklung und Gliedmassenchwäche ("Leg Weakness") bei Schweinen. Dtsch. Tierärztl. Wschr., 74, 1967: 336-338

THURLEY, D. C.-DONE, J. T.: The histology of myofibrillar hypoplasia of newborn pigs. Zbl. Vet. Med. A., 16, 1969: 732-740

THURLEY, D. C.-GILBERT, F. R.-DONE, J. T.: Congenital splayleg of piglets: myofibrillar hypoplasia. Vet. Rec., 80, 1967: 302-304

WARD, P. S. - BRADLEY, R.: The light microscopical morphology of the skeletal muscle of normal pigs and pigs with splayleg from birth to one week of age. J. Comp. Path., 90, 1980: $421-431$

ZELENÁ, J.-JIRMANOVA, I.: Degenerative changes in skeleton muscles of piglets with congenital myofibrillar hypoplasia. Zbl. Vet. Med. A, 26, 1979: 652-665 


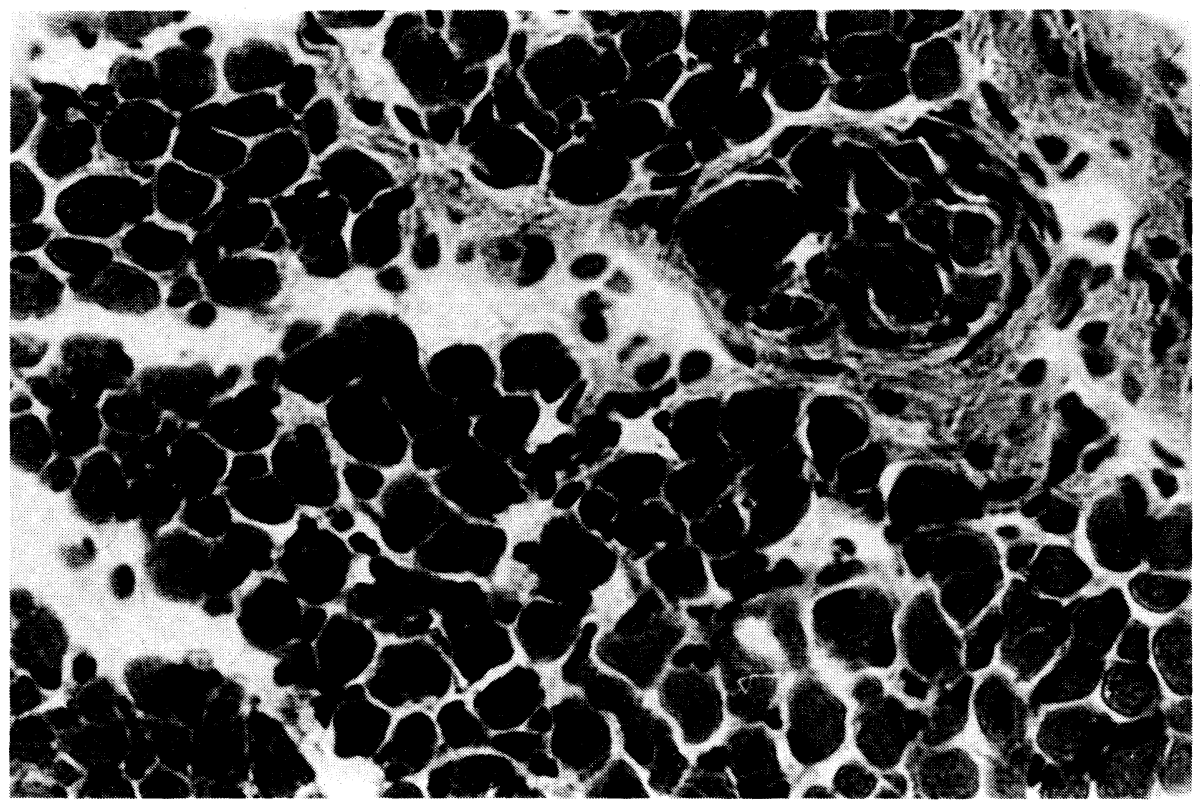

Fig. 1: A complete morphological differentiation of extra - and intrafusal muscle fibres (MFs) is characterized by the fact that the fibres are entirely filled with myofibrils, the primary and the secondary population of extrafusal fibres are of the same thickness, fibres are predominantly polygonal in transversal cross-sections (CS) and cellular nuclei are placed subsarcolemmally. Clearly visible is a neuromuscullar spindle (NMS) with 2 markedly thicker and 6 thinner intrafusal MFs. M. semitendinosus, CS, hematoxylin-eosin (HE); $\times 252$.

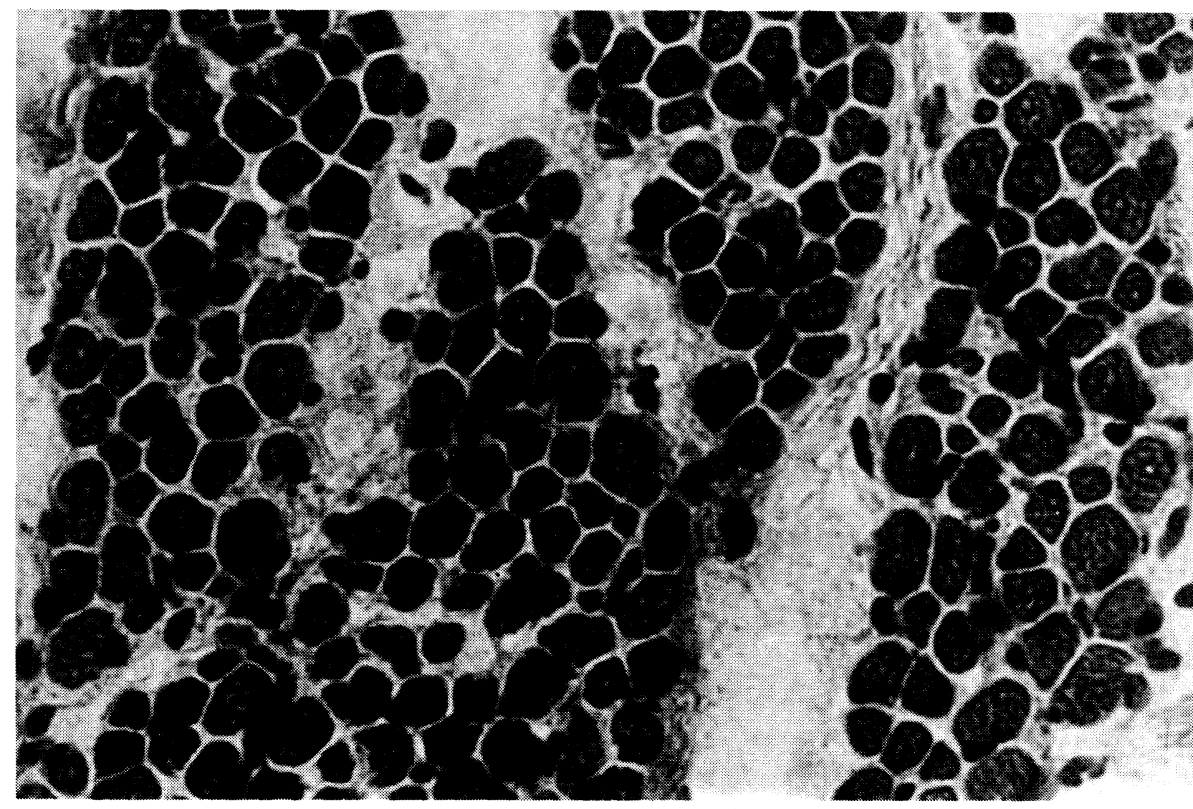

Fig. 2: M. trapezius, CS, HE. Completed morphological differentiation, sporadic remains of myotubal lumina pointing to a primary MF. A characteristically nolvgonal CS. thickness of both MF populations almost balanced; $\times 252$. 
Plate XVIII.

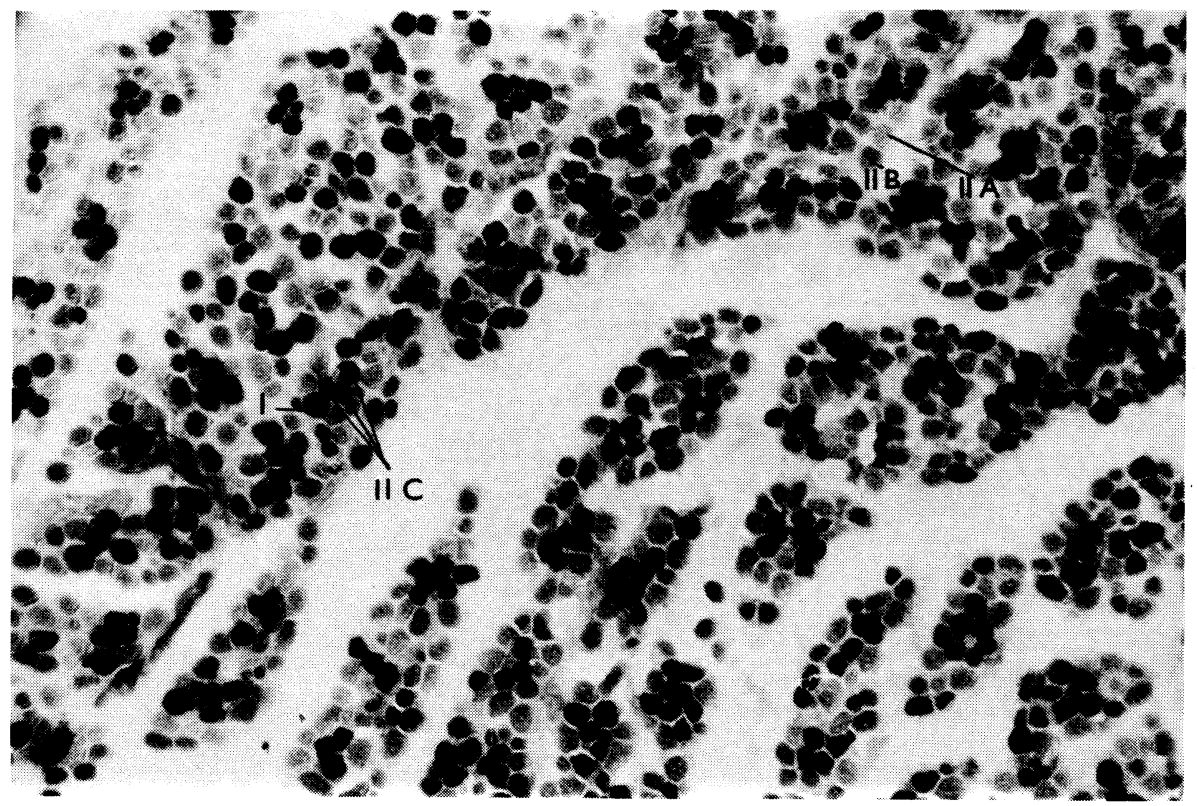

Fig. 3: A detection of myosin Ca-ATPase after an acid pre-incubation ( $\mathrm{pH} 4,3$ ) shows a high degree of histochemical differentiation. A striking, relatively high number of strongly reacting MFs (acidostable MF I, and intermediary MF IIC). The remaining MFs, reacting more weakly or weakly, represent the more primitive MF II, differentiated into lighter MF IIA and darker IIB in places; m. trapezius, $\times 101$.

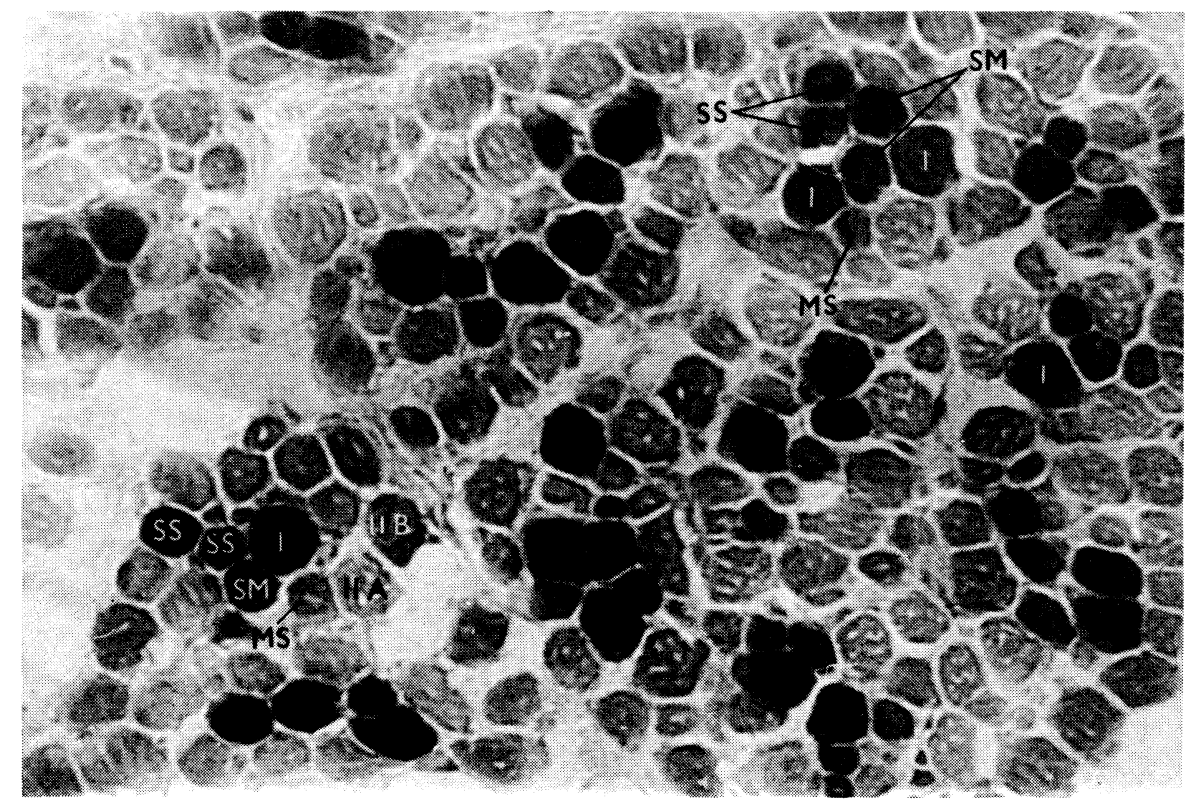

Fig. 4: MF type differentiaton with differences in myosin Ca-ATPase reaction after an acid pre-incubation. M. trapezius, a detailed view from Fig. 3: $\times 252$. I = MF I; IIA, IIB = differentiated Type II fibres; MS; SS = transformation subtypes of intermediary MFs of Type IIC. 


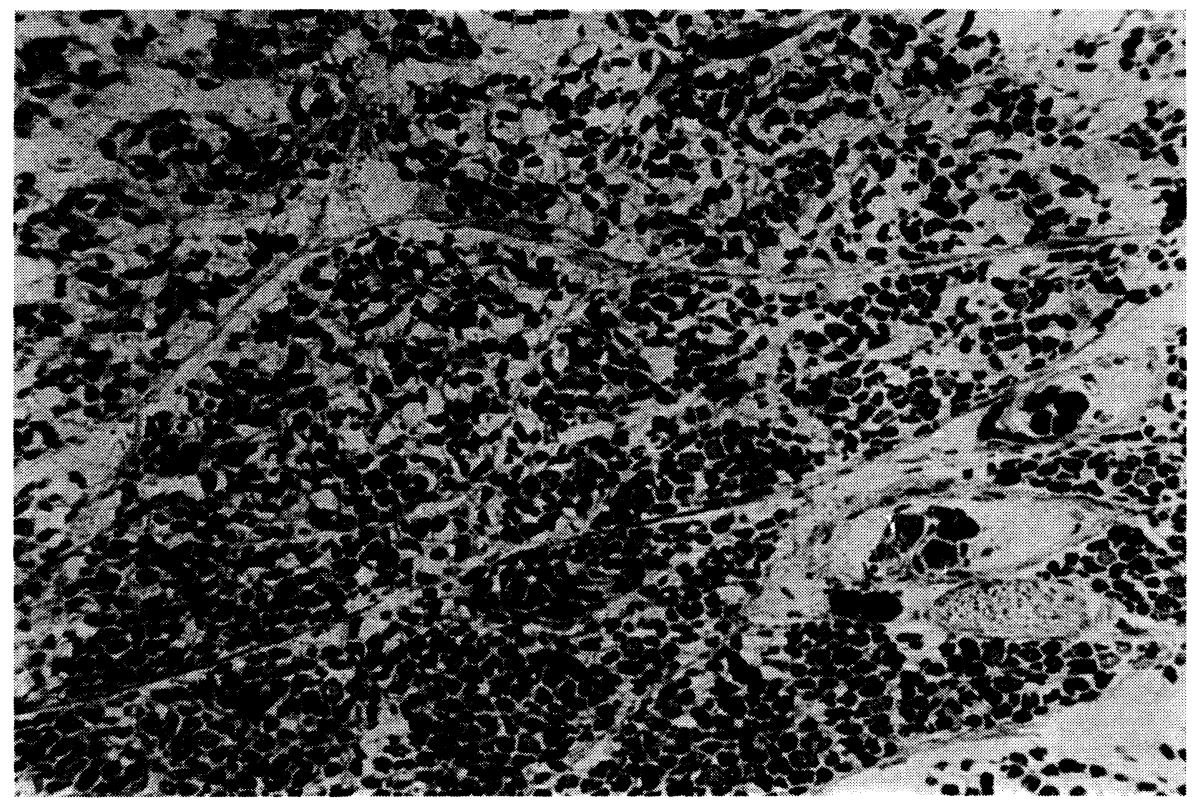

Fig. 5: A detection of myosin Ca-ATPase after an alkaline pre-incubation (pH 9.2) in a section from the $\mathrm{m}$. longissimus dorsi. The deeper portion is more compact and differentiated, the more superficial muscle component is less compact. Taken from a muscle of a low-weight newborn. Also recorded here are two neuromuscullar spindles. In the lower one, the thicker 2 fibres exhibit a weak rection, in analogy to MF I, and the remaing ones react as strongly as MF II; in thee upper NMS, all fibres exhibit a strong reaction; $\times 63$.

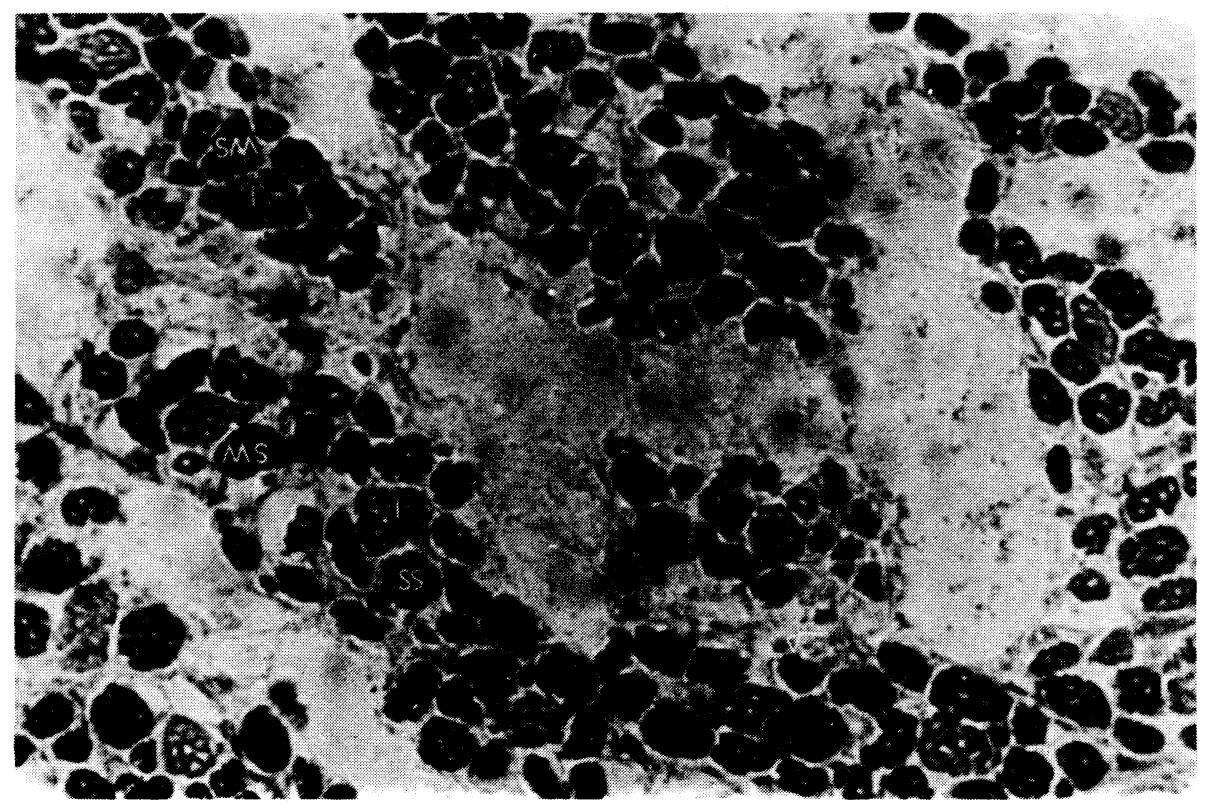

Fig. 6: A detailed view of a surface area of the $\mathrm{m}$. longissimus dorsi from Fig. 5. The histochemical reaction is highly positive, with a marked type differentiation of muscle fibres. A disproportion between the thickness of the primary and secondarv fibres still noticeable; $\times 252$. 


\section{Plate XX.}

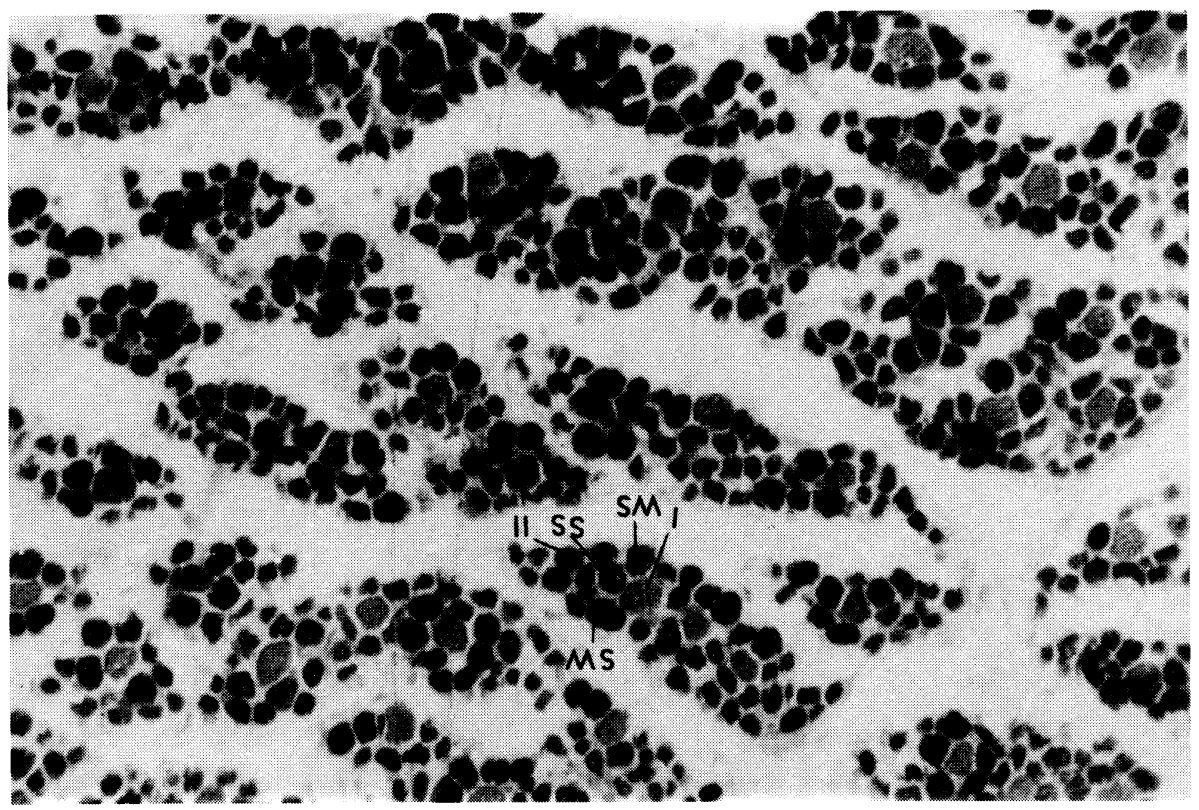

Fig. 7: Ca-ATPase activity after an alkaline pre-incubation at $\mathrm{pH} 9.4$ in the $\mathrm{m}$. longissimus dorsi of another newborn with a higher body weight. The reaction with different densities of the reaction product differentiated between fibres of Type I and IIC with subtypes MS, SS and SM; $\times 80$.

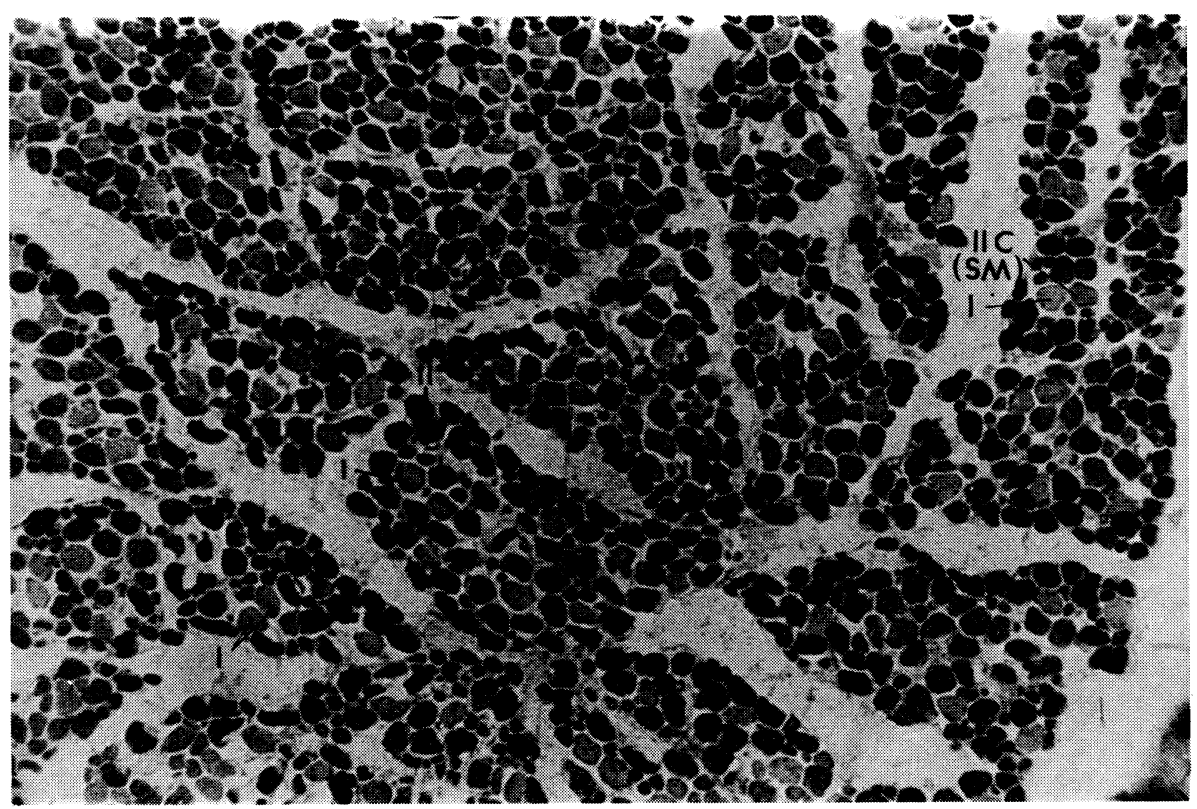

Fig. 8: M. triceps brachii, caput longum. The myosin Ca-ATPase after an alkaline pre-incubation at $\mathrm{pH} 9.4$ documents a high degree of morphological and histochemical differentiation and muscle compactness. In the centre of primary muscle bundles (MB), 1 but also frequently 2 alkali unstable, weakly reacting fibres corresponding to Type I fibres are visible. Somewhat darker MFs of the transformation subtype SM of the intermediary MF IIC were found in places. In muscle bundles. strongly reacting MFs of Tve II were 


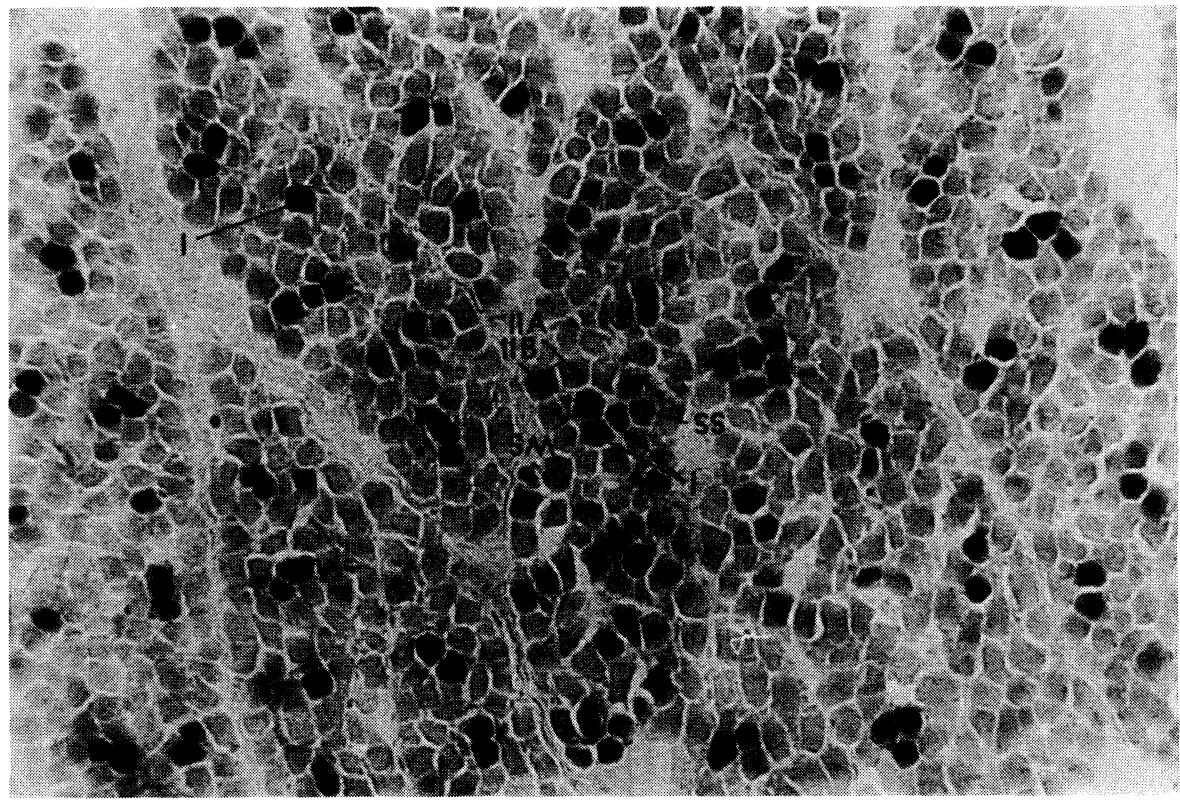

Fig. 9: The myosin ATPase reaction after an acid pre-incubation. Acidostable fibers show a very strong reaction, the acid unstable ones are significantly weaker. A comparison of this reaction with the myosin ATPase reaction after an alkaline pre-incubation (Fig. 10) allows an identification of strongly reacting acid-stable fibres as MF I and transformation subtypes SS and SM of intermediary MF IIC. Other muscle fibres in primary bundles are classified as MF II. M. triceps brachii, caput longum; $\times 101$.

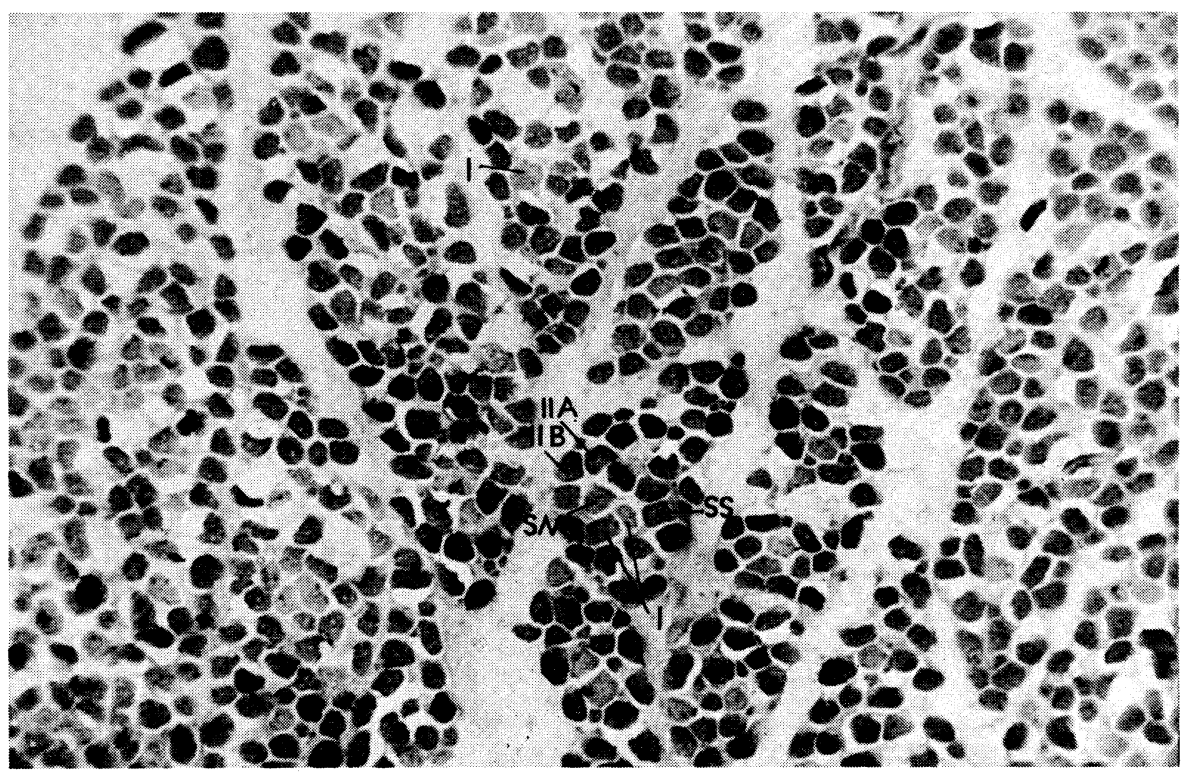

Fig. 10: An inversion of Fig. 9 from a serial section after an alkaline pre-incubation at $\mathrm{pH}$ 9.4. The reaction intensity of alkali unstable fibres is low, that of alkali stable ones is high, i. e. we obtain an inverse image necessary for an objective fibre type differentiation. Muscle bundles of the left half contain patches that mint ha idantifiad se mvnfihrillar doficionev hv mistake. Checking with 